Jurnal Kesmas Asclepius

Volume 1, Nomor 2, Desember 2019

e-ISSN: 2684-8287

p-ISSN: 2656-8926

DOI: https://doi.org/10.31539/jka.v1i2.947

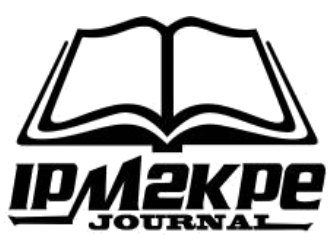

\title{
FAKTOR YANG MEMPENGARUHI KESULITAN BERHENTI MEROKOK PADA MAHASISWA AKPER KESDAM I/BB MEDAN
}

\author{
Ade Irma Khairani ${ }^{1}$, Suvi Novida ${ }^{2}$, Muchti Yuda Pratama ${ }^{3}$ \\ Akademi Keperawatan Kesdam I/Bukit Barisan Medan ${ }^{1,2,3}$ \\ muchtiyuda@kesdammedan.ac.id ${ }^{3}$
}

\begin{abstract}
ABSTRAK
Penelitian ini bertujuan untuk mengetahui faktor-faktor yang memengaruhi kesulitan mahasiswa Akper Kesdam I/BB Medan berhenti merokok. Desain penelitian yang akan digunakan adalah kualitatif deskriptif dengan pendekatan studi fenomenologi. Hasil penelitian didapatkan semua informan mulai merokok pada saat masih duduk di bangku sekolah. Dari 12 informan, didapatkan $6(50 \%)$ informan mulai merokok pada saat duduk di bangku SMA, 4 (33\%) informan mulai merokok pada saat duduk di bangku SMP, dan didapatkan $2(17 \%)$ informan mulai merokok pada saat masih duduk di bangku SD. Simpulan, faktor kesulitan mahasiswa Akper Kesdam I/BB Medan berhenti merokok adalah diri sendiri (personal), adiksi rokok, pengaruh lingkungan sosial, teman sebaya, kemudahan mendapatkan rokok dan adanya orang yang menjadi panutan merokok.
\end{abstract}

Kata Kunci: Berhenti Merokok, Faktor Kesulitan

\begin{abstract}
This study aims to determine the factors that influence the difficulty of Akper Kesdam I I $B B$ Medan students to stop smoking. The research design that will be used is descriptive qualitative with a phenomenological study approach. The results showed all informants started smoking while still in school. From 12 informants, found $6(50 \%)$ informants started smoking while sitting in high school, 4 (33\%) informants started smoking while sitting in junior high school, and found $2(17 \%)$ informants started smoking while still sitting in elementary school. Conclusion, the difficulty factor for the students of Akper Kesdam I / BB Medan to stop smoking is self (personal), addiction to cigarettes, the influence of the social environment, peers, ease of getting cigarettes and the existence of people who become role models of smoking.
\end{abstract}

Keywords: Stop Smoking, Difficulty Factors 


\section{PENDAHULUAN}

Perilaku merokok masih merupakan masalah kesehatan dunia karena dapat menyebabkan berbagai penyakit dan bahkan kematian (Lizam, 2009). Perokok berisiko untuk terkena kanker hati dan paru, bronkitis kronis, emphysema, gangguan pernapasan, kerusakan dan luka bakar, berat badan rendah dan perkembangan yang terhambat pada bayi (Taylor, 2006). Selain itu, rokok juga dapat mengakibatkan gangguan reproduksi pada pria dan wanita (Nurhayati, 2008). Aktifitas yang secara langsung dapat diamati pada remaja laki-laki adalah perilaku merokok. Perilaku merokok adalah perilaku yang dinilai sangat merugikan dilihat dari berbagai sudut pandang baik bagi diri sendiri maupun orang lain disekitarnya (Aula \& Lisa, 2010).

Merokok adalah suatu kebiasaan menghisap rokok yang dilakukan dalam kehidupan sehari-hari, merupakan suatu kebutuhan yang tidak bisa dihindari bagi orang yang mengalami kecenderungan terhadap rokok. Kebiasaan merokok dianggap dapat memberikan kenikmatan bagi perokok, namun di lain pihak dapat menimbulkan dampak buruk bagi perokok sendiri maupun orang-orang disekitarnya. Hal ini sebenarnya telah diketahui oleh masyarakat, bahwa merokok itu mengganggu kesehatan. Masalah rokok pada hakekatnya sudah menjadi masalah nasional (Setiyanto, 2013).

Merokok merupakan suatu masalah di dalam masyarakat yang dapat menimbulkan banyak kerugian baik dari segi sosial ekonomi maupun kesehatan bahkan kematian (Kementrian Kesehatan Republik Indonesia, 2011). Rokok merupakan hasil dari olahan tembakau yang terbungkus, termasuk cerutu atau bentuk lainnya yang dihasilkan dari tanaman nicotiana tobacum, nicotiana rustica dan spesies lainnya atau sintetisnya yang mengandung nikotin, tar, dan zat adiktif dengan atau tanpa bahan tambahan (Gubernur Daerah Istimewa Yogyakarta, 2009). Masalah utama yang ditimbulkan rokok adalah adanya peningkatan prevalensi perokok yang menjadi semakin tinggi tiap tahunnya (Ardita, 2016).

Semua ahli kesehatan termasuk World Health Organization (WHO) telah lama menyimpulkan, bahwa secara kesehatan rokok banyak menimbulkan dampak negatif, lebih bagi anak-anak dan masa depannya. Rokok mengandung 4000 zat kimia dengan 200 jenis di antaranya bersifat karsinogenik (dapat menyebabkan kanker), dimana bahan racun ini didapatkan pada asap utama yaitu asap rokok yang terhisap langsung masuk ke paru-paru perokok maupun asap samping yaitu asap rokok yang dihasilkan oleh ujung rokok yang terbakar, misalnya karbon monoksida, benzopiren, dan amoniak (KPAI, 2013; Rahayu \& Purwanti, 2017).

Menurut World Health Organization (WHO), "Health is a complete state of physical, mental, and social being and not merely the absence of disease or infirmity." (sehat adalah suatu keadaan sejahtera secara fisik, mental dan sosial yang menyeluruh dan bukan hanya bebas dari penyakit cacat dan kelemahan). Berdasarkan UndangUndang (UU) Republik Indonesia nomor 36 Pasal 1 tahun 2009 tentang kesehatan, kesehatan adalah keadaan sehat, baik secara fisik, mental, spiritual maupun sosial yang memungkinkan setiap orang untuk hidup produktif secara sosial dan ekonomis.

Menurut Global Adult Tobacco Survey (GATS) (2015) laki laki Indonesia menduduki rangking pertama di dunia dengan prevalensi $67 \%$, diikuti Rusia dengan 61\%. Riset Kesehatan Dasar (Riskesdas) tahun 2013 menyebutkan bahwa Daerah Istimewa Yogyakarta (DIY) memiliki persentasi perokok aktif dengan usia penduduk diatas 10 tahun sebesar $21,2 \%$. 
Umumnya perokok aktif maupun pasif tidak menyadari bahwa di dalam sebatang rokok terdapat ribuan senyawa kimia, yang 43 diantaranya merupakan zat karsinogenik (Kementrian Kesehatan Republik Indonesia, 2012). Jumlah perokok semakin hari semakin meningkat di berbagai negara di dunia, baik di negara-negara yang sudah maju maupun negara yang sedang berkembang. Prevalensi penyakit yang salah satu faktornya disebabkan oleh rokok semakin meningkat namun hal ini tidak membuat orang menghentikan kebiasaan perilaku merokok (Soedarmadji, 2011).

Disisi lain masyarakat kususnya para pemuda telah tercemar oleh mitos-mitos yang menyesatkan. Rokok dianggap sebagai simbol kedewasaan dan kejantanan bagi laki-laki, jika seorang laki-laki tidak merokok dianggap masih kecil dan banci. Target dari mitos tersebut adalah para remaja laki-laki yang sedang mencari jatidirinya. Mereka yang psikologisnya masih labil sehingga gampang sekali terpengaruh oleh mitos seperti itu. Dalam faktanya tidak hanya laki-laki yang merokok, perempuan juga merokok bahkan ada juga nenek-nenek yang merokok, ini artinya merokok bukanlah lambang kedewasaan dan kejantanan laki-laki sejati (Muchtar, 2009).

Kondisi fisik, mental, spiritual dan sosial yang sehat maka manusia dapat beraktifitas dengan sempurna sehingga kesehatan merupakan salah satu hal terpenting dalam kehidupan manusia yang harus dijaga dan disyukuri. Pada kenyataannya masih banyak orang yang dengan sengaja atau tidak sengaja merusak kesehatan mereka dengan perilaku-perilaku yang tidak sehat, yakni salah satunya berupa perilaku merokok.

Rokok dapat menyebabkan kanker, serangan jantung, impotensi, gangguan kehamilan dan janin. Pesan ini tertera dalam setiap bungkus rokok yang ada di Indonesia. Setiap perokok, sebelum mengambil dari bungkus rokok dan menghisapnya akan membaca tulisan tersebut (Widati, 2013).

\section{METODE PENELITIAN}

Desain penelitian yang akan digunakan adalah kualitatif deskriptif dengan pendekatan studi fenomenologi. Penelitian kualitatif adalah jenis penelitian yang menghasilkan penemuan-penemuan yang tidak dapat dicapai (diperoleh) dengan menggunakan prosedur-prosedur statistik atau dengan cara-cara lain dari kuantifikasi (pengukuhan).

Studi fenomenologi yaitu penelitian yang menjelaskan pengalaman manusia melalui deskripsi dari orang yang menjadi informan penelitian, sehingga peneliti dapat memahami pengalaman hidup informan. Metode penelitian ini ditekankan pada subjektivitas pengalaman hidup dari perokok yang berkaitan dengan kesulitan berhenti merokok.

\section{HASIL PENELITIAN \\ Mulai Merokok}

Hasil penelitian didapatkan semua informan mulai merokok pada saat masih duduk di bangku sekolah. Dari 12 informan, didapatkan 5 (41,66\%) informan mulai merokok pada saat duduk di bangku SMA.

\section{Penyebab Merokok}

Hasil penelitian didapatkan bahwa informan merokok disebabkan karena adanya beberapa faktor, yaitu lingkungan pergaulan teman sebaya, mencoba-coba, kejenuhan, mengisi waktu luang, ingin terlihat gaya atau keren dan anggota keluarga perokok. 


\section{Motivasi Berhenti Merokok}

Hasil penelitian didapatkan bahwa secara umum hampir semua informan mempunyai keinginan dan mencoba untuk berhenti merokok. Adapun intensitas berhenti merokok antar informan berbeda-beda. Informan berhasil berhenti merokok dalam beberapa hari, beberapa minggu, dan bahkan beberapa bulan. Hal ini disebabkan motivasi antar informan yang berbeda pula. Motivasi tersebut timbul karena adanya beberapa faktor yaitu diri sendiri, kesehatan, lingkungan, tuntutan dariluar, ekonomi.

\section{Upaya Berhenti Merokok}

Hasil penelitian didapatkan bahwa upaya beberapa perokok untuk berhenti merokok dilakukan dengan beberapa cara, yaitu menghindar dari komunitas perokok, niat diri sendiri atau merubah sugesti, makan cemilan, mengurangi porsi rokok, puasa, mengalihkan dengan kegiatan lain.

\section{Kesulitan Berhenti Merokok}

Hasil penelitian didapatkan bahwa hampir semua perokok ingin berhenti merokok, pernah berhenti merokok tetapi kembali merokok sampai sekarang. Hal tersebut disebabkan karena beberapa faktor seperti faktor, yaitu pergaulan teman, diri pribadi, faktor lingkungan, faktor orang yang menjadi panutan.

\section{PEMBAHASAN}

Hasil penelitian pengumpulan data didapatkan bahwa sebagian besar perokok mulai merokok pada usia sekolah. Dari 12 informan, didapatkan $6(50 \%)$ informan mulai merokok pada saat duduk di bangku SMA, 4 (33\%) informan mulai merokok pada saat duduk di bangku SMP, dan 2 (17\%) informan mulai merokok pada saat masih duduk di bangku SD. Secara umum informan mulai merokok saat usia antara 12-18 tahun.

Umumnya perokok aktif maupun pasif tidak menyadari bahwa didalam sebatang rokok terdapat ribuan senyawa kimia, yang 43 diantaranya merupakan zat karsinogenik (Kementrian Kesehatan Republik Indonesia, 2012). Jumlah perokok semakin hari semakin meningkat di berbagai negara di dunia, baik di negara-negara yang sudah maju maupun negara yang sedang berkembang. Prevalensi penyakit yang salah satu faktornya disebabkan oleh rokok semakin meningkat namun hal ini tidak membuat orang menghentikan kebiasaan perilaku merokok (Soedarmadji, 2011).

Rokok dapat menyebabkan kanker, serangan jantung, impotensi, gangguan kehamilan dan janin. Pesan ini tertera dalam setiap bungkus rokok yang ada di Indonesia. Setiap perokok, sebelum mengambil dari bungkus rokok dan menghisapnya akan membaca tulisan tersebut (Widati, 2013).

Melihat dari efek efeknya yang begitu banyak terhadap kesehatan, tidak mengherankan jika 70\% perokok ingin berhenti merokok (Ukwayi et al., 2012). Berhenti merokok dipengaruhi oleh niat dan motivasi. Motivasi adalah suatu proses psikologis yang mencerminkan interaksi antara sikap, kebutuhan, persepsi dan keputusan yang terjadi pada diri seseorang (Ayu, 2014). Faktor-faktor yang mempengaruhi motivasi untuk berhenti merokok ada dua yaitu faktor intrinsik meliputi usia, pengetahuan, nilai dan persepsi, pengalaman, sedangkan faktor ekstrinsik meliputi lingkungan, orang terdekat (keluarga), ekonomi (Marquis \& Huston, 2000 dalam Barus, 2012). 
Menurut Ardita (2016) dalam penelitiannya yang berjudul faktor-faktor yang mempengaruhi motivasi berhenti merokok pada mahasiswa teknik mesin Universitas Muhammadiyah Yogyakarta angkatan 2015 yang menyatakan bahwa terdapat hubungan yang signifikan antara faktor kontrol diri terhadap motviasi berhenti merokok pada mahasiswa Teknik Mesin UMY angkatan 2015.

Banyak pecandu rokok yang berusaha untuk berhenti dari perilaku merokok baik karena kesadaraan diri atau karena anjuran orang lain. Namun usaha yang dilakukan selalu menemukan jalan buntu (kegagalan). Adapun yang membuat seseorang sulit berhenti merokok adalah nikotin karena bersifat adiktif, sehingga membuat seorang perokok menjadi kecanduan secara fisik dan emosional. Apabila seorang perokok menghentikan kebiasaannya, ia pasti akan tersiksa, baik secara fisik maupun mentalnya. Walaupun begitu beberapa diantara mereka yang memiliki niat dan tekad yang kuat ada juga yang berhasil meloloskan diri dari siksaan candu (Aula \& Lisa, 2010).

Menghentikan perilaku merokok bukanlah usaha mudah, terlebih lagi bagi perokok di Indonesia. Hasil survei yang dilakukan oleh LM3 (Lembaga Menanggulangi Masalah Merokok) dari 375 responden yang dinyatakan 66,2 persen perokok pernah mencoba berhenti merokok, tetapi mereka gagal (Muchtar, 2009). Global Youth Tobacco Survey melaporkan $76 \%$ perokok ingin berhenti merokok, $86 \%$ telah mencoba berhenti tahun sebelum survei dilakukan tetapi gagal. Berdasarkan Peraturan Pemerintah nomor 19 tahun 2003 tentang pengamanan rokok bagi kesehatan, tempat proses belajar mengajar merupakan kawasan tanpa rokok. Hasil survei pendahuluan dari 10 mahasiswa perokok 7 mahasiswa perokok ingin berhenti merokok tetapi mengalami kesulitan berhenti merokok (Aditama et al., 2008).

Meskipun semua orang mengetahui tentang bahaya yang ditimbukan akibat rokok, tetapi hal ini tidak pernah surut dan hampir setiap saat dapat ditemui banyak orang yang sedang merokok bahkan perilaku merokok sudah sangat wajar dipandang oleh para remaja, khususnya remaja laki-laki (Susilo, 2009). Ada 3 fase klinik penting dalam kecanduan tembakau yaitu mencoba, kadang-kadang menggunakan, menggunakan setiap hari (Subanda, 2008). Seperti penggunaan zat-zat (substances) lainnya, terdapat beberapa faktor bagi remaja sehingga mereka menjadi perokok, misalnya faktor psikologi, faktor biologi, faktor lingkungan (Subanda, 2008).

Faktor penyebab informan merokok adalah faktor lingkungan sosial, teman sebaya, diri sendiri dan lingkungan keluarga atau adanya orang tua yang merokok. Penelitian yang dilakukan oleh Rohayatun et al., (2015) menyatakan bahwa faktor penghambat untuk berhenti merokok pada penelitian ini adalah keinginan merokok karena melihat teman $(86,4 \%)$, dipengaruhi teman (59\%) dan agar dapat bergabung dengan teman-teman pergaulan (54,5\%). Hasil penelitian Baequni \& Narila (2005) menyatakan bahwa seorang perokok pertama kali merokok dipengaruhi oleh teman, diri sendiri dan keluarga. Yunita (2008) juga mengungkapkan bahwa seseorang merokok disebabkan pengaruh teman sebaya dan orang tua yang merokok.

Hal ini sejalan dengan penelitian Kumboyono (2012) dimana didapatkan 69\% responden mengenal rokok dari temannya. Mu'tadin (2002) juga mengemukakan bahwa perilaku merokok dapat terjadi karena terpengaruh oleh teman16. Hal ini diperkuat dalam pernyataan Safitri (2010) bahwa salah satu pengaruh teman sebaya adalah dalam pembentukkan kebiasaan merokok sehingga sulit untuk berhenti merokok.

Penelitian Rahmadita (2013) didapatkan 53,6\% peran dan fungsi efektif keluarga yang baik berhubungan dengan derajat merokok seseorang menjadi ringan. Begitu pula dengan penelitian yang dilakukan Sulastri \& Arina (2011) kurangnya dukungan teman 
sebaya cenderung memiliki perilaku merokok tinggi.

Penelitian ini juga sejalan dengan penelitian yang dilakukan oleh Nubai et al., (2012) yang menyatakan bahwa faktor personal, pengaruh lingkungan sosial, faktor teman sebaya, faktor kemudahan mendapatkan rokok dan faktor adanya orang yang menjadi panutan merokok dapat mempengaruhi kesulitan mahasiswa UIN Jakarta berhenti merokok.

Secara umum hampir semua informan mempunyai keinginan dan mencoba untuk berhenti merokok. Adapun intensitas berhenti merokok antar informan berbeda-beda. Informan berhasil berhenti merokok dalam beberapa hari, minggu, dan beberapa bulan. Hal ini disebabkan motivasi antar informan yang berbeda pula. Motivasi tersebut timbul karena adanya beberapa faktor yaitu faktor internal, (diri sendiri dan kesehatan) dan eksternal (lingkungan dan ekonomi).

Al Naggar et al., (2011) dalam penelitiannya menjelaskan bahwa, seseorang yang memiliki kontrol diri yang baik cenderung memiliki perilaku yang baik dan dapat menahan diri dari perbuatan yang dapat memberikan efek negatif di kemudian hari. Penjelasan tersebut sesuai dengan hasil jawaban responden yang mengatakan bahwa responden terbanyak merasakan ada kontrol diri didalam diri mereka sebanyak 88,9\% diikuti $92,6 \%$ responden menjawab benar pada pernyataan nomor 2 , mengenai keinginan responden untuk menujukkan padanya dirinya sendiri bahwa responden mampu dan bisa untuk berhenti merokok yang membuktikan bahwa kontrol diri cenderung dapat membuat responden menahan keinginan merokok sebagai pembuktian diri. Selain itu, penjelasan mengenai kontrol diri dapat dijadikan tameng terbukti dengan jawaban responden yang menunjukkan bahwa $87 \%$ responden menjawab benar pada pernyataan nomor 8 tentang perasaan responden jika responden mampu untuk berhenti merokok yang menunjukkan bahwa kontrol diri memicu adanya keinginan untuk berhenti merokok.

Upaya informan dalam mencoba berhenti merokok dilakukan dengan berbagai macam cara yaitu mengurangi porsi secara bertahap, menghindari lingkungan perokok, olahraga, dan mengalihkan keinginan merokok dengan melakukan kegiatan lain. Secara umum upaya yang dilakukan bertujuan untuk menghindari efek psikoaktif nikotin yang sangat kuat. Sani mengatakan efek psikoaktif nikotin 5-10 kali lebih kuat dari kokain dan morfin.

Disisi lain masyarakat kususnya para pemuda telah tercemar oleh mitos-mitos yang menyesatkan. Rokok dianggap sebagai simbol kedewasaan dan kejantanan bagi laki-laki, jika seorang laki-laki tidak merokok dianggap masih kecil dan banci. Target dari mitos tersebut adalah para remaja laki-laki yang sedang mencari jatidirinya. Mereka yang psikologisnya masih labil sehingga gampang sekali terpengaruh oleh mitos seperti itu. Dalam faktanya tidak hanya laki-laki yang merokok, perempuan juga merokok bahkan ada juga nenek-nenek yang merokok, ini artinya merokok bukanlah lambang kedewasaan dan kejantanan laki-laki sejati (Muchtar, 2009).

Penelitian yang dilakukan oleh Ardita (2016) menyatakan bahwa faktor kontrol diri didominasi oleh kontrol diri yang tinggi dan memiliki motivasi berhenti merokok yang tinggi, yaitu sebanyak 39 responden (72,2\%). Puspitadesi et al., (2013) menyatakan dimana dewasa awal telah mampu memandu, mengarahkan dan mengatur perilaku. Kemampuan untuk mengendalikan dirinya sendiri bahkan dapat menghentikan perilaku yang tidak sesuai. 
Hal tersebut sesuai dengan hasil yang didapatkan oleh peneliti pada pernyataan nomor 15 bahwa responden akan merasa mencapai suatu hal yang penting apa bila dapat berhenti merokok, selain itu $88,9 \%$ responden merasakan adanya kontrol diri dalam diri mereka untuk mengurangi bahkan berhenti merokok.

Penelitian sebelumnya pernah dilakukan oleh Ukwayi et al., (2012) di University of Calabar Nigeria dengan menyebarkan kuisioner secara random pada semua fakultas didapatkan sebanyak 29\% mahasiswa adalah perokok yang disebabkan oleh faktor stres. Selain itu berdasarkan penelitian yang dilakukan Al Naggar et al., (2011) pada Management and Science University di negara Malaysia sebanyak 20\% mahasiswa merokok diakibatkan oleh stres dengan prevalensi paling banyak pada mahasiswa lakilaki dan pada tingkat semester akhir. Selain itu menurut penelitian sebelumnya yang penah dilakukan oleh Kusumawati et al., (2015) di fakultas ilmu kesehatan Universitas Muhammadiyah Surakarta menjelaskan bahwa mahasiswa kesehatan dengan pengetahuan tinggi tentang bahaya merokok ternyata banyak yang merokok dan mereka kesulitan untuk berhenti merekok, selain itu juga dijelaskan bahwa merubah perilaku mahasiswa untuk tidak merokok butuh kerja keras.

Dari berbagai cara yang dilakukan informan untuk berhenti merokok sebagian besar bahkan bisa dikatakan semua informan mengalami kegagalan karena sebagian informan yang berhasil berhenti merokok kembali merokok. Kegagalan tersebut disebabkan adanya beberapa faktor. Faktor kesulitan informan untuk berhenti merokok adalah diri sendiri (tidak ada keinginan yang kuat dari dalam), lingkungan, teman sebaya, orang yang menjadi panutan, dan sifat adiktif rokok bahwa hampir semua kampus terdapat aturan larangan merokok di kampus walaupun ada keluhan dari beberapa mahasiswa tentang penerapan aturan tersebut.

\section{SIMPULAN}

Berdasarkan penelitian yang telah dilakukan maka dapat disimpulkan sebagai berikut yaitu perilaku merokok pertama kali dimulai pada masa remaja yaitu saat berusia 12-18tahun. Faktor yang dapat menyebabkan orang merokok adalah pengaruh lingkungan sosial, teman sebaya, diri sendiri (personal), lingkungan keluarga, dan ketersediaan rokok di lingkungan sekitar. Perokok mempunyai keinginan untuk berhenti merokok disebabkan karena beberapa faktor yaitu keinginan diri sendiri, lingkungan yang mendukung untuk tidak merokok, kesehatan, dan faktor ekonomi.

Upaya untuk berhenti merokok dapat dilakukan dengan berbagai macam cara yaitu mengurangi porsi secara bertahap, menghindari lingkungan perokok, olahraga, dan mengalihkan keinginan merokok dengan melakukan kegiatan lain.

Faktor kesulitan mahasiswa Akper Kesdam I/BB Medan berhenti merokok adalah diri sendiri (personal), adiksi rokok, pengaruh lingkungan sosial, teman sebaya, kemudahan mendapatkan rokok dan adanya orang yang menjadi panutan merokok.

\section{SARAN}

Akper Kesdam I/BB Medan merupakan tempat pendidikan yang sepantasnya memberikan contoh kepada intstitusi lain atau masyarakat dalam menciptakan area pendidikan tanpa perilaku merokok.

Perlu adanya program pendidikan atau promosi kesehatan yang lebih terintegrasi dengan sosialisasi secara menyeluruh tentang bahaya merokok kepada mahasiswa, contohnya seperti menyebarkan famplet, poster, aklirik, serta mengadakan seminar tentang keuntungan tidak merokok maupun bahaya merokok yang diselenggarakan oleh 
pihak Universitas dengan melibatkan pihak kampus, pihak program studi, dan organisasi kemahasiswaan.

Perlu adanya penerapan aturan larangan merokok yang maksimal untuk mempersempit ruang gerak perokok contohnya seperti pengawasan penerapan aturan larangan merokok.

Membatasi atau menghilangkan ketersediaan rokok dari lingkungan Akper Kesdam I/BB Medan, contohnya mengurangi atau menghilangkan ketersediaan rokok di kantin semua kampus dengan adanya surat edaran dari pihak universitas.

Sebagai orang yang menjadi panutan (seperti: dosen, karyawan, serta civitas akademik) sewajarnya memberikan contoh untuk tidak merokok di lingkungan Akper Kesdam I/BB Medan.

\section{DAFTAR PUSTAKA}

Aditama, T. Y., Pradono, J., Rahman, K., Warren, C. W., Jones, N. R., Asma, S., \& Lee, J. (2008). Linking Global Youth Tobacco Survey (GYTS) data to the WHO Framework Convention on Tobacco Control: the Case for Indonesia. Prev Med, 1(11). doi: 10.1016/j.ypmed.2008.05.003

Al-Naggar, R .A., Al-Dubai, S. A., Al-Naggar, H. T., Chen, R., \& Al-Jashamy, K., (2011). Prevalence and Associated Factors of Smoking among Malaysia University Students. Asian Pacific J Cancer Prev, 12(3), 619-624. https://www.researchgate.net/publication/51179247

Ardita, H. (2016). Faktor-faktor yang Mempengaruhi Motivasi Berhenti Merokok pada Mahasiswa Teknik Mesin Universitas Muhammadiyah Yogyakarta angkatan 2015. Universitas Muhammadiyah Yogyakarta

Aula, A., \& Lisa, E. (2010). STOP Merokok! Sekarang atau Tidak Sama Sekali. Yogyakarta: Gara Ilmu

Ayu, Z. W. (2014). Tingkat Ketergantungan Merokok dan Motivasi Berhenti Merokok pada Pegawai FKG USU dan Supir Angkot Medan. Universitas Sumatra Utara

Baequni, B., \& Narila, N. (2005). Gambaran Perilaku Merokok Civitas Akademika UIN Syarif Hidayatullah Jakarta. Jurnal Medika Islami, 2(1)

Barus, H. (2012). Hubungan Pengetahuan Perokok Aktif tentang Rokok dengan Motivasi Berhenti Merokok pada Mahasiswa FKM dan FISIP Universitas Indonesia. Universitas Indonesia

Departemen Kesehatan RI. (2009). Undang-Undang Republik Indonesia Nomor 36 Tahun 2009 Tentang Kesehatan. Jakarta: Kementrian Kesehatan RI: 2009

GATZ. (2015). The GATS Atlas Global Tobacco Surveillance System. Atlanta, GA: CDC Foundation

Kementrian Kesehatan Republik Indonesia (Kemenkes RI). (2011). Informasi tentang Penanggulangan Masalah Merokok melalui Radio, Jakarta

Kementrian Kesehatan Republik Indonesia. (2012). Kemenkes Luncurkan Survei Tembakau. from Departemen Kesehatan Republik Indonesia: http://www.depkes.go.id/article/print/2048/kemenkes-luncurkan-hasil-surveitembakau.html

KPAI. (2013). Menyelamatkan Anak dari Bahaya Rokok. (http://www.kpai.go.id/tinjauan/menyelamatkan-anak-dari-bahaya-rokok/)

Kumboyono, K. (2012). Hubungan Perilaku Merokok dengan Motivasi Belajar Anak Usia Remaja di SMK Bina Bangsa Malang. Universitas Brawijaya 
Kusumawati, Y., Astuti, D., Darnoto, S., Wijayanti, A. C., Setiyadi, N. A. (2015). Model Pemberdayaan Konseling Peer Education Upaya Membentuk Perilaku Berhenti Merokok pada Mahasiswa. University Research Colloquium, 5(3), 104115. publikasiilmiah.ums.ac.id

Lizam, C. T. (2009). Meningkatkan Sikap Positif terhadap Perilaku Tidak Merokok dan Kecenderungan untuk Berhenti Merokok melalui Pelatihan Kecerdasan Emosional pada Mahasiswa SMA di Kabupaten Aceh Barat Daya Nanggroe Aceh Darussalam. Yogyakarta: Universitas Gadjah Mada

Mu'tadin, Z. (2002). Kemandirian sebagai Kebutuhan Psikologis pada Remaja. (Online). Available : http://www.e-psikologi .com/remaja.050602.html

Muchtar, M. (2009). Siapa Bilang Merokok Makruh?). Jakarta: Bhuana Ilmu Populer

Nubai, A. R., Ernawati, E., Utomo, W. B. (2012). Analisis Kualitatif Faktor yang Mempengaruhi Kesulitan Mahasiswa Universitas Islam Negeri Syarif Hidayatullah Jakarta Berhenti Merokok. Universitas Islam Negeri Syarif Hidayatullah Jakarta

Nuryati, S. (2008). Hampir 90\% Wanita Muda Indonesia Perokok. (Online). Available : http://indotc.4umer.com/your-first-forum-f1/Tobacco

Puspitadesi, D. I. Yuliadi, I., \& Nugroho, A. A. (2013). Hubungan antara Figur Kelekatan Orangtua dan Kontrol Diri dengan Perilaku Seksual Remaja SMA Negeri 11 Yogyakarta. Jurnal Ilmiah Psikologi, 1(4), 1-10. https://studylibid.com/doc/164500

Rahayu, P., \& Purwanti, O. S. (2017). Hubungan antara Pengetahuan Bahaya Merokok dengan Perilaku Merokok pada Mahasiswa di Universitas Muhammadiyah Surakarta. Universitas Muhammadiyah Surakarta

Rahmadita, E. (2013). Hubungan Pelaksanaan Peran dan Fungsi Afektif Keluarga terhadap Derajat Merokok pada Perokok Aktif Siswa Laki-Laki(13-15 Tahun) di SMP 3 Ungaran. Jawa Tengah : STIKES

Rohayatun, R., Saptiko, S., \& Yanti, Y. (2015) Faktor-Faktor yang Mendukung dan Menghambat Perokok untuk Berhenti Merokok Puskermas Kampung Bali Pontianak. Jurnal Cerebellum, 4(4). Universitas Tanjung Pura

Safitri, S. (2010). Remaja dan Rokok. Yogyakarta: Makalah Fakultas Psikologi UGM

Setiyanto, R. (2013). Faktor-Faktor Penyebab Merokok. Bandung: Alfa Beta

Soedarmadji, S. (2011). Kajian Faktor yang Mempengaruhi Perilaku Berhenti Merokok di Lapangan Panas Bumi X Tahun. Universitas Indonesia

Subanda, I. B. (2004). Tumbuh Kembang Remaja dan Permasalahannya. Jakarta: Sagung Seto

Sulastri, S., \& Arina, U. H. (2011). Hubungan antara Dukungan Orang Tua, Teman Sebaya dan Iklan Rokok dengan Perilaku Merokok pada Siswa Laki-Laki Madrasah Aliyah Negeri 2 Boyolali. Jawa tengah: Gaster

Susilo, S. (2009). Psikologi Sosial. Surabaya: Jenggala Pustaka Utama

Taylor, S. E. (2006). Health Psychology-Chapter 6: Health-Compromising Behaviour (3rd ed.). Singapore: McGraw-Hill International Studies

Ukwayi, J. K., Eja, O. F., \& Unwanede, C. C. (2012). Peer Pressure and Tobacco Smoking among Undergraduate Student of University of Calabar, Cross River $\begin{array}{llll}\text { State. Higher } & \text { Education }\end{array}$ http://dx.doi.org/10.5539/hes.v2n3p92 
Widati, S. (2013). Efektifitas Pesan Bahaya Merokok pada Bungkus Rokok terhadap Perilaku Merokok Masyarakat Miskin. Jurnal Promosi Kesehatan, 1(2), 105-110. http://journal.unair.ac.id/download-fullpapers-jupromkes17f9558da7full.pdf

Yunita, R. (2008). Hubungan antara Perilaku Merokok Orangtua dengan Perilaku Merokok Siswa SMP di Kota Bogor. Universitas Indonesia 